\title{
Social Conventions and Human Tragedy in Richard Jefferies' "The Acorn-gatherer"
}

\author{
Zhengfeng Chen \\ Xi'dian University \\ Xi'an, China
}

\author{
Pei Zheng \\ Xi'dian University \\ Xi'an, China
}

\begin{abstract}
Richard Jefferies is a British writer well-known for his novel on the history, rural life and agriculture in the late Victorian England. His works, The Acorn-gather, through the lonely life and silent death of a little boy, accounts for the rigid social conventions and human tragedy of lower-strata people in rural areas in the process of industrialization, which distorts the human image. This paper explores how the work displays the hard and miserable human life while presenting the readers the beautiful nature, which has a deep influence on the modern society.
\end{abstract}

Keywords-The Acorn-gather; social conventions; human tragedy; reality

\section{INTRODUCTION}

John Richard Jefferies (1848 - 1887) was an English nature writer, noted for his depiction of English rural life in essays, books of natural history, and novels. His childhood on a small Wiltshire farm had a great influence on him and provides the background to all his major works of fiction. For all that, these show a remarkable diversity, including Bevis (1882), a classic children's book, and After London (1885), an early work of science fiction. For much of his adult life, he suffered from tuberculosis, and his struggles with the illness and with poverty also play a role in his writing. Jefferies valued and cultivated an intensity of feeling in his experience of the world around him, a cultivation that he describes in detail in The Story of My Heart (1883). This work, an introspective depiction of his thoughts and feelings on the world, gained him the reputation of a nature mystic at the time. But it is his success in conveying his awareness of nature and people within it, both in his fiction and in essay collections such as The Amateur Poacher (1879) and Round about a Great Estate (1880) that has drawn most admirers. Richard Jefferies, writes a host of novels on the history, rural life and agriculture in the late Victorian period, which shows that he has a deep passion for the countryside life and believes the life is eternal. Living in the countryside, accompanied by the air, the ocean, the trees, the hedges, and

[Fund Project] Shaanxi Education Science Program (SGH17H050) in 2017: The Research on the Construction of O2O College English Teaching Model in the Post- MOOC Era; Xi'an Social Science Fund Project

（17Y27） in 2017: Cultural Confidence Studies of College English

Teaching in Xi'an under the Background of Internationalization ; The Basic Scientific Research Business College of Xi'dian University(RW170403) in 2017and (RW170116) in 2017; The Study of the Spiritual and Cultural Needs of the Faculty from the Point of Cultural Self-confidence of Xi'dian University Union in 2017. the grass, is beneficial for him to have deep insights into the nature. This has built social foundation for him to write the novel in his later life.

Richard Jefferies lived in the Victorian period - the transition of agriculture into the industrialization. As the industrial movement swept England in the 19th century, many farmers and agriculture workers found themselves in devastation. In this period, the society was three-tiered. The working class's work was more visible in society. Their labor was very physical and dirty, which showed every day in their clothes and their hands. Most people of the working class were paid a daily or weekly wage. Men of the middle classes did the clean work, which normally included mental, not physical work they were usually paid a monthly or yearly salary. The elite included the aristocracy and the landed gentry. People in the countryside lived in poverty "Widespread poverty and wretchedness among the people" is very serious. (changyaoxin, 2003: 4) The problems of jobless are serious in the countryside while the output of the agriculture is on the increase. The peasants live in the poverty. The Acorn-gatherer", based on this background, illustrates the wretchedness of the poor child and the beauty of the nature, which shows the tragedy of human life and the cruelty of the reality. This paper tells the readers the human tragedy and how the social conventions and environment ruin one's life.

\section{THE ANALYSIS OF THE STORY}

There are certain characteristics of this age which are clearly noticeable: This age emphasized the moral purpose. So the novel seeks for society in this age precisely to find the truth and to show how it might to uplift humanity. Perhaps for this reason the Victorian Age is emphatically an age of realism rather than of romance, which strives to tell the whole truth, showing moral and physical diseases as they are, and holding up health and hope as the normal conditions of humanity.

It is also an age of doubt and pessimism. "a boy asleep at the foot of the tree. In his slumber his forehead frowned they were fixed lines, like the grooves in the oak bark. There was nothing else in his features attractive or repellent: they were such as might have belonged to a dozen hedge children." Here, it is obviously seen that the boy lives a strenuous and miser able life with bad fate. As for the boy, he should enjoy the happiness with his innocent mind in the 
childhood as well and live a comfortable life with his beloved parents. "set angry frown" and "the iron set frown on the young brow would not have unbent even for the silver". Through the silent sleep with set frown and fixed lines, sympathy arouses in my heart. In contrast to that cheerful scene, the boy is not playing, laughing as we imagined. When the rooks, "the happiest creatures in the world fluttering up there and hopping from branch to branch, the sidling out to the extreme end of the bough, and the inward chuckling when a friend lets his acorn drop tip-tap from bough to bough. Amid such plenty they cannot quarrel or fight, having no cause of battle, boasting of success, and do so to the loudest of their voices" Surrounded the boy with "Caw" here and there happily and freely, a promising and harmonious scene appears - "a thrush looked out from the hedge, and among the short grass there was still the hum of bees, constant sun-worshipers as they are. The sunshine gleamed on the rooks' black feathers overhead, and on the sward sparkled from hawk-weed, some lotus and yellow weed, as from a faint ripple of water" The happiness belongs to the rooks instead of the boy. How poor a boy is! Who should be responsible for the happiness of the boy?

Furthermore, his granny uses sticks to beating the boy many times with pride as she does her duty. Her beating skills are so skillful that she beats the boy without any hesitation and forms the habit of slashing the boy. When the old woman finds the child is sleeping, she "came back towards the boy, keeping him between her and the corner". Then "thwack, thwack, bang, went the ash stick on the sleeping boy, heavily enough to have broken his bones." Even though he was awaken just now. The old woman "had him again, thwack, thwack, and one last stinging slash across his legs as he doubled past her". Under all the harsh beating, the boy never uttered any sound, speechless, only knowing to pick up the acorns and run away. His "How many times he has been beaten like this so that he may forget to shout and find it's useless to beg for excuse." She treated the grandson like that! Any child may scream and shout or even defend himself by screaming for mercy. But the boy does not. "Like a piece of machinery suddenly let loose, without a second of dubious awakening and without a cry, he darted straight for the gap in the corner," Living in this environment, the boy wanted to escape from beating habitually. In addition, beating is not the only way to punish him but also the starvation. "One morning, after a severe beating, she drove the boy in there and locked him in the whole day without food." Here, as for life can be understood and be touched by the people in modern society. What makes the old woman mercilessly beat her grandson?

According to social conventions, "Her religion lifted her above the rest," "A footpath which crossed the field went by the cottage and every Sunday those who were walking to church could see the boy in the window with granny's Bible open before him. There he had to sit, the door locked, under terror of stick, and study the page." It can be seen that she is pious and faithful to the religion. "He won't read, but I make him look at his book." The punishment of the boy through the beating and starvation seems to tell others and god. "The Bible and the Evangelical Orthodoxy were regarded either as outdated superstition or tested by the principal of utility" (Changyaoxin, 2003: 4). "Utilitarianism was ready accepted and practiced." (Changyaoxin, 2003: 5). At that time, she has to survive, facing the cruel reality undertaking the burden of raising her grandson, the illegitimate boy. The conventions make her do the duty bring him up, simultaneously, which distorts her into the merciless women by using the ash stick to beat the grandson.

In the story, the author emphasizes the power of religion. Her belief in the religion is so ridiculous and hypocritical that people have to laugh at her. In addition, she compelled the grandson to believe religion in front of bible he did not like and that is beyond him. What a poor creature for the child! But what a poorer creature she is for the old lady to do so! "She was very clean, well dressed for a laboring woman, hard of feature, but superior in some scarcely defined way to most of her class." It can be inferred he is elegant and graceful but merciless to the poor children duty. Seemingly she is noble in favor of Bible but loses conscience for the innocent child. The granny is too cruel to her grandson to lose her morality and also is innocent in her mind. It can be inferred that the granny is elegant and also is innocent in her mind. Maybe it is not. As for her, she should take good care of her grandson well instead of beating him frequently. Why does it make her like that? As a matter of fact, the granny should show the beloved kindness to the grandson without any suspicion. Her beating is a kind of obedience to the social conventions - the rigid religion. It is the religion that makes the granny beat the child skillfully and habitually again and again. She is the absolute saint and is warmhearted and pious to the God However, what on earth does make the child suffer from beating?

Why does her daughter die of starvation? This sentence "the girl died, as was believed, of sheer starvation:" reminds us that they live a very hard and tragic life in the countryside. The mother, granny, should help her daughter to live a happy life. Probably the daughter makes the unforgivable mistakes from the point of her mother.

Parents 'love is much more important to the child anything else in the world. So does the granny to her daughter. But sarcastically, her mother does not do like this. Indeed, According to social conventions, in the Victorian period, people do something with the obedience to social conventions. In front of religion and distorted rules, the people are numb. The social conventions make the girl die. She loses her spontaneous love, instinct love to the children. But always remembers the responsibility for the religion. The boy is seemed to be doomed from the birth. "He was her grandson - at least, the son of her daughter, for he was not legitimate. Eventually the child was drowned to death. His father does not care about it, neither show any true love to his son, on the opposite, abandoning him to the granny.

No one stops the tragedy from happening on his helpless child. At that time, the boy made no sound, not asking for help. "This was why the dead boy had gone so willingly, thinking to fish in the "river", as he called the canal. "When his feet slipped and he fell in, his fishing-line somehow became twisted about his arms and legs, most likely he 
would have scrambled out, as it was not very deep." For a boy, the future is beautiful which is full of unknown mysteries. The boy's death may be is a kind of relief for his suffering "This was why the dead boy had gone so willingly, thinking to fish in the "river", as he called the canal." He has no choice but to accept the fate-death.

The villagers in the countryside show the indifference and selfishness to the boy. No one cares about the boy. As for the old woman, she always said, "She had done her duty", "A wicked boy never lived", "Beat him from habit as one of the ordinary events of the day". Here she just makes the excuses for her beating the boy. "No, he won't read, but I make him look at his book." In the end after the boy's death, she comforted herself "she had done her duty". When the boy drowns in the river, a dealer "who had business in a field by the canal thought indeed that he saw something in the water, but he did not want any trouble, nor indeed did he know that someone was missing. The dealer thinks that doing businesses is more crucial to him than helping the child. The same is true of the steers woman, who even know "what it was, but she "wanted to reach the wharf and go ashore and have a quart of ale. No use picking it up, only making a mess on deck." The steers woman thinks drinking the beer is much more significant to her than the child. The child is nothing in her eyes. "Most likely a dead dog", from this — a dead dog, the readers understand the dealer was excusing himself for not rescuing and reckoning the boy's life was so cheap that it's unworthy of rescuing. All these quotations depict the people's indifference to the dignity of life. In that social climate, the main stream society was largely indifferent to the misery of illegitimate, abandoned children, and unruly lower class youth were treated with disdain. Stereotyped concepts are still killing children, adults and the whole society.

First of all, the boy falls asleep at the foot of the trees but his granny frequently slashes him, which does not make him sleep in a comfortable way. Moreover, there is a sharp difference between the beauty of nature and child's life. The nature is beautiful as the author depicted in the novel. It can be seen that people can live happily and harmoniously with the nature, enjoying the beauty of the nature and cherish the beauty of nature. The rooks are his sole friends. The rooks are happy but the child is in sorrow. Only by playing with the rooks and picking up the fruits, the child is happy. This is a part of his life. But his granny destroys the beauty of nature, the harmonious relations between the child and the rooks. The rooks also show the protests of the granny. Every time when the granny goes towards the oak trees, the rooks shout: "Caw Caw! Thwack, thwack". The child, the being oppressed, the protest against the granny is powerless and helpless. At the end of the novel," "This was not the end; nor was he even remembered." The boy had been talked to, and held up as a scarecrow all his life: he was dead, and that is all. As for granny, she felt no twinge: she had done her duty." The child's death just likes the dead dog as well as the hung scarecrow.

In this novel, the child only plays with the rooks, and the ales and no any other companions around him. We can't see the happiness of him together with other children in his children. Even we don't his real name, only knowing that the Acorn-gatherer is connected with the nature, "The happiest creatures in the world are the rooks at the acorns." and "This was going on above while the boy slept below." These two sentences show the happiness of rooks and the sadness and loneliness of the child. He can't enjoy the love of parents and sympathy of people. Who will cry for the child in the society? No one has mercy on them. So it is really a tragedy for human being. "It was beautiful summer weather." This sentence shows the striking comparison between the social cruelty and human tragedy and the nature.

The innocent child is the substitute of sacrifice of human being which is warned that people should be the obedience of the religion and morality in the society. There are lots of similarities between the child and the rooks. They are lively and the part of nature. It is just because of them that makes the world in harmony with the nature. The death of the child displays the fate that people does not obey the social conventions in the countryside during the transition of the agriculture into the industrialization. In the process of the industrialization, people become selfish, lack of morality, numb and detached.

\section{THE REALITY}

Here, conspicuously, it can be seen that the social conventions - people's stereotyped views prohibit people from doing something good. In some way, the social conventions, especially the rules of the religion affect people's ideas seriously. Even worse, it distorts people's images, which is not beneficial for the progress of mankind civilization. Human tragedy, the two victims - the boy and the old woman, is also made by the society. Victorian era is a prosperous and flourishing age in English history. Although many developed things appear in that era, there are also many bad things, such as some outdated rules, bad habits to control people, many excessive ceremonies and some hypocritical moralities to confine people. From the tragic story of The Acorn-gathers, we can see in a deeper sense that it is the capitalist society of the time that has ruined the boy. Living in a society overwhelmed by capitalist law, religion and state apparatus, a poor an illegitimate child, inevitably leads a tragic life and finally goes to death. The tragedy evokes my sympathy. If the boy was born in a rich and harmonious family, things could be totally different. In that case, tortured by the granny and the social conventions, death may be the best heaven and freedom to him.

\section{CONCLUSION}

In a word, through the above analysis, it is obvious that, people's ignorance and the cruelty as well as the granny beating the boy mercilessly, are the direct causes of human tragedy. But these direct causes are deeply rooted in the cruel social environment: the impoverished peasant, the unjust law and cruel convention. So it can be drawn that the social conventions are the real and root cause of human tragedy. By studying The Acorn-gather, I can better understand Richard Jefferies comprehensively and objectively, which embodies the progressive significance of his novel in English literature.

The Acorn-gather, this novel has far-reaching influences on the society nowadays. If the leader only confines the idea to the framework and the rules, he cannot achieve anything in his career .If the economic and political reform in china does work, the reformer must escape from the limitations of social conventions. Otherwise more Acorn-gathers will appear in the process of the social development. As for the individual, we should seek for the endless opportunities to develop the abilities for the society and create something 
new for the society instead of obeying the rigid, useless, outof-date patterns of the rules. Only when we realize the importance of adaption to the society through the deep understanding of the social conventions can we know what we should do and fulfill the task with the appropriate conventions. As for the English teachers, we should teach the students in a different and flexible way and cultivate the students' ability to learn the language well rather than using the out-of-dated method mechanically.

\section{REFERENCES}

[1] http://booka.guardian.co.uk/departments/scienceandnature/story/0,60 00,1100944,00.html,december 6,2003.

[2] http://en.wikipedia.org/wiki/Richard_Jefferies.

[3] http://blog.sina.com.cn/s/blog4588a9f80100bz72.html

[4] http://wenku.baidu.com/view/f93ea7c24028915f804dc201.html

[5] Henry, J. The Art of Fiction[M]. Shanghai: Shanghai Translation Press. 2001

[6] Jefferies. The Acorn-gatherer [A] Yujianhua and Yangziwu,the translator. The Appreciation of Famous English Essay [C]. Shanghai: Shanghai Foreign Language Education Press. 1995.

[7] Changyaoxin. English and American literature course Beijing: Higher Education Press, 2003:4-5 